\title{
APPLICATION OF DISTANCE LEARNING TOOLS IN TEACHING UKRAINIAN LANGUAGE AS A FOREIGN FOR STUDENTS OF NON-PHILOLOGICAL SPECIALTIES
}

\author{
Uvarova Tetiana Yuriivna, \\ $\mathrm{PhD}$ in Pedagogy, \\ Associate Professor at the Departament of language training \\ Kharkiv National Automobile and Highway University \\ uvarova hnadu@ukr.net \\ orcid.org/0000-0001-8502-2441
}

In the process of studying Ukrainian language by foreign students, along with traditional teaching methods that imply "live communication", the means of distance education are also of prime importance. They have a sufficient amount of advantages over other forms of studies. Thus, during distance learning, the communication skills of foreign citizens are improved both in educational and extracurricula situations, which facilitate to the accelerated and high-quality learning of educational material, and are also easy to use. Owing to telecommunication technologies, for example, video communication, foreign students are able to keep regular contact with the teacher even while in another country. The practical training materials can be quickly obtained electronically. The article describes the definition of the concept of "distance learning", its concept and forms of implementation. It is outlined that the primary purpose of distance education is to provide knowledge and educational materials with the help of modern information and communication technologies. The use of distance learning tools in teaching Ukrainian as foreign language to students of non-philological specialties is considered. The results of the experimental research are analyzed, namely the introduction of a distance course for part-time students. The advantages and disadvantages of distance learning are considered. The effectiveness of the combined type of training is noted. A number of arguments are presented to prove that the introduction of distance learning will contribute to the successful adaptation of foreign students to studying at universities in Ukraine. It is recommended to further create certain educational distance learning programs that will contribute to the satisfaction of the communicative needs of foreign non-philologist students in extracurricula times and ensure the independent work of students with all the necessary educational materials.

Key words: distance learning, tools, distance course, Ukrainian as a foreign language, non-philologists.

\section{ЗАСТОСУВАННЯ ЗАСОБІВ ДИСТАНЦІЙНОГО НАВЧАННЯ ПІД ЧАС ВИКЛАДАННЯ УКРАЇНСЬКОЇ МОВИ ЯК ІНОЗЕМНОї ДЛЯ СТУДЕНТІВ НЕФІЛОЛОГІЧНИХ СПЕЦІАЛЬНОСТЕЙ}

\author{
Уварова Тетяна Юріївна \\ кандидат педагогічних наук, \\ доцент кафедри мовної підготовки \\ Харківський національний автомобільно-дорожній університет \\ uvarova hnadu@ukr.net \\ orcid.org/0000-0001-8502-2441
}

\begin{abstract}
У процесі вивчення української мови іноземними студентами разом із традиційними методами навчання, які передбачають «живе спілкування», чільне місце посідають і засоби дистанційної освіти. Вони мають достатню кількість переваг перед іншими формами навчання. Так, під час дистанційного навчання покращуються комунікативні навички іноземних громадян як у навчальних, так і в позанавчальних ситуаціях, що сприяє прискореному та якісному засвоєнню навчального матеріалу, а також є зручними у використанні. Завдяки телекомунікаційним технологіям, наприклад, відеозв' язку, іноземні студенти мають змогу підтримувати регулярний контакт з викладачем, навіть перебуваючи в іншій країні. Практичний навчальний матеріал можна оперативно отримати в електронному вигляді. У статті наводиться визначення поняття «дистанційне навчання», його концепція та форми реалізації. Окреслюється, що основна мета дистанційної освіти полягає у наданні знань та навчальних матеріалів за допомогою сучасних інформаційно-комунікаційних технологій. Розглядається застосування засобів дистанційного навчання під час викладання української мови як іноземної студентам нефілологічних спеціальностей. Аналізуються результати експериментального дослідження, а саме впровадження дистанційного курсу для студентів заочної форми навчання. Розглядаються переваги та недоліки дистанційного навчання. Відзначається ефективність комбінованого виду навчання. Наводиться низка
\end{abstract}


доводів на доказ того, що впровадження дистанційного навчання сприятиме успішній адаптації іноземних студентів до навчання у закладах вищої освіти України. Рекомендується подальше створення певних навчальних дистанційних програм, які сприятимуть задоволенню комунікативних потреб іноземних студентів-нефілологів у позааудиторний час та забезпечуватимуть самостійну роботу студентів усіма необхідними навчальними матеріалами.

Ключові слова: дистанційне навчання, засоби, дистанційний курс, украйнська мова як іноземна, студенти-нефілологи.

Introduction. Modern society is characterized by the dominance of knowledge and information in all spheres of human life, the influence of information and communication technologies on the development of civilization is also noticeable.

Since, being educated in Ukraine, foreign students study in a foreign for them language (Ukrainian or English), the process of their language training becomes especially important, and the main task of this process is the formation of communicative competence. Taking into account modern demands of the new society for the educational process requires the updating of modern educational technologies, in particular linguodidactics, at the same time there is a need to use the newest means of developing the communicative competence of foreign students studying in the Ukrainian universities.

These trends have led to the formation of a global information space. In the conditions of creating the mobility of world educational systems, distance education is becoming increasingly important for Ukraine. On the border of the XX-XXI centuries the theoretical foundations are actively studied and technologies of distance education are developed. This is due to the fact that "the system of distance education allows the widest and most complete use of all learning opportunities of information technology" (Krechetnikov K.G., 2001). In recent years, at the Kharkiv National Automobile and Highway University and the V. N. Karazin Kharkiv National University appeared foreign students of correspondence form of training of educational qualification level "bachelor", requiring educational services through distance learning. For these foreign students, the language of study is Ukrainian, and therefore the need has arisen to create a distance course in the Ukrainian language for foreign non-philology students of correspondence form of training, the main goal of which is to form communicative competence in the sociocultural, educational and professional fields of communication.

\section{Theoretical substantiation of the} problem

Problems of introducing electronic distance courses into the educational process of the universities are researched by such scientists of Ukraine, Russia, Kazakh- stan, as A. N. Anisimov, A. Kh. Hilmutdinov, R. A. Ibrahimov, I. V. Tsyvilskyi and others. Different aspects of distance learning of Russian as a foreign language are covered in the researches by $A$. N. Bohomolov and O. A. Uskova (Bogomolov A.N., Uskova O.A., 2004), who reviewed the native and foreign information technologies and techniques "Distance learning of Russian as a foreign language". Scientists consider technologies of creating the resources for distance learning of Russian as a foreign language, existing types of educational, methodological and reference information resources, they also describe the characteristics of distance learning in Russia and abroad, the directions of development of the methodology of distance learning of Russian language as a foreign language. We consider it expedient to use the existing theoretical developments when creating a distance course in Ukrainian for foreign students of technical specialties.

Studies indicate that distance learning has a number of advantages: the availability of the course at any time; unlimited information provided; the efficiency of providing information; the flexibility of the organization of the educational process; automation of educational process; multimedia. The listed advantages justify the expediency of using distance learning tools during the formation of Ukrainian-speaking communicative competence of foreign students of Ukrainian universities.

The purpose of the paper is to analyze the advantages and disadvantages of using distance learning tools when teaching Ukrainian language to foreign students of non-philological specialties.

\section{Methodology and methods}

Problems of creating distance education in the post-Soviet space are discussed since the late 90-ies of the XX century, but at the present stage, these discussions are moving "from the plane of conversation and theoretical search for the development of distance learning in the plane of real incarnation" (Malitikov E.M et al., 2001: 16). Russian scientists created the concept of distance learning (Aksenov lu.V., et al., 1998) and defined the forms of its implementation. "Under distance learning is meant an individualized process 
of acquiring knowledge, skills, and methods of cognitive activity of a person, which occurs predominantly with the indirect interaction of distant participants of the educational process in a specialized environment. Such training functions on the basis of modern psychological and pedagogical, information and communication technologies" (Order of the Ministry of Education and Science of Ukraine "On Approval of the Regulations on Distance Learning", 2013). The use of the named technologies will allow the creation of a system for the continuous learning of the Ukrainian language for foreign students of correspondence form of training.

"The goal of distance learning is to provide educational services through the use of modern information and communication technologies in teaching at certain educational or educational qualification levels in accordance with state educational standards; according to the programs for preparing citizens for entering educational institutions, training foreigners and professional development of employees" (idem).

Therefore, in order to provide educational services fully on the language of instruction (Ukrainian) for students of correspondence form of training of non-philology specialties, we have developed and implemented a distance learning course on the Ukrainian language in the educational process. The following methods were used to test the effectiveness of the course: a pilot training project using an author' $s$ distance course, highlighting the effectiveness of creative communication and professional-oriented tasks; team competition training; monitoring of the educational process.

I. Participants. Studying at the author's course "Ukrainian language for foreign non-philology students", students have the opportunity to train and practice communicative skills in small groups or in pairs. It helps students develop the ability to work in the team (listen, express thoughts, negotiate, etc.) and independently (focus on time management and problem solving), and also contributes to the development of self-study skills and the search for new information in the Ukrainian language, selfassessment of learning outcomes.

The training experiment was held at the V. N. Karazin Kharkiv National University in 2016. It was attended by 29 nonphilology students of both correspondence and stationary forms of education. The latter used the distance learning platform, performing their independent work in the number of hours according to the university' $s$ academic curriculum. Let us note that all participants in the experiment possessed the basic level of the Russian language, which resulted in a certain methodological orientation in the organization of language material for a distance course in the Ukrainian language. The conclusions of the experiment proved that the participants have attained the necessary level of proficiency in the Ukrainian language, which will ensure that foreign students master the skills in perceptual and productive types of speech activity in the field of educational and professional communication; the acquisition of language and professionally oriented knowledge by foreign students for the implementation of the communicative goal and satisfaction of the necessary communicative needs in the field of educational and professional communication.

II. Apparatus and materials. The program of the distance course of the Ukrainian language has the structure and content identical to the program of full-time education, but is calculated on the number of hours and credits allocated by the normative documents for the correspondence form of training. According to the requirements for the structure of a distance course, it must contain material sufficient for the student to master the full amount of knowledge and skills provided by the curriculum of the discipline (Andreev A.A., 1997). This approach enables foreign students of correspondence form of training to acquire knowledge and improve communicative skills from the course "Ukrainian language for foreign non-philology students" in the amount not less than full-time students receive.

The distance learning course used in the experimental study has a transparent structure, which containsthefollowing elements: 1) general information about the discipline being studied; 2) a set of recommendations for students regarding the sequence and timing of the study of materials as a whole discipline, and its individual elements; 3) general recommendations on how to perform various types of educational, practical and independent work of the student; 4) general criteria for assessing the knowledge, skills and abilities that must be obtained by the student in the learning process, and the system for assessing the student' $s$ knowledge, skills and abilities; 5) informative educational and teaching materials; 6) methodical recommendations for the organization of independent work of the student concerning the learning of the educational material and the implementation of all types of educational work; 7) the forms and terms of interactive collaboration between students 
and teachers during the semester; 8) sets of tasks and tests for checking and controlling knowledge, skills and abilities of students in the course of studying discipline (intermediate control); 9) examples of correct answers to all tasks on the verification of student knowledge; 10) Web resources and software required for the implementation of practical training activities; 11) system of interactive communication of students among themselves.

All described elements are combined into four blocks: instructional, informational, communicative and controlling.

The instructional block is represented by the "Course Script" element, which includes recommendations for students regarding the sequence and time of studying the material and the conditions for conducting current and final module control.

The information block has two components: a theoretical material selected according to the requirements of the Distance Learning Program, and practical tasks (for the formation of the communicative competence of foreign students). Due to this block, students are introduced to the main aspects of the subject being studied and perform practical tasks, taking into account the instructions prepared by the teacher. The multimedia technologies give the teacher wide opportunities for submitting the course material and creating a foreign language communicative space.

The communicative block exists in the form of a forum where students can receive and discuss news about the organization of training within the course of the Ukrainian language in offline mode, and chat created for conducting online consultations.

The control block (current thematic control) involves checking and assessing the level of formation of the communicative competence of foreign students. To familiarize students with the assessment system, they are asked to study in detail the course element, such as "The Scale of Assessment", which contains a table and comments.

III. Procedure. The implemented distance learning course "Ukrainian language for foreign non-philology students" allowed to create a micro-social educational network, for example, a chat room for discussion of organizational issues by the teacher and students. Through this network, the complex of tasks aimed at the formation of the communicative competence of foreign students takes place: 1) language, transformational, substitution, questionanswer, conditional speech and speech exercises (according to the classification of Yu. I. Pasov) 2) personalized role-playing games; 3) problem tasks.
Creating a permanent communicative process with the elements of cooperation greatly increased the motivation for performing tasks for independent work. Thus, personal inclusiveness of students in the continuous information-speech activity in the interactive mode of performance of tasks, their public presentation and assessments in the microsocial educational network was ensured.

The stage of public presentation and evaluation allowed using the means of assessing the academic achievements of foreign students-philologists after performing independent work.

Let us give an example of the implementation of the above-mentioned elements of the distance course on the conversational theme "My Family".

To master the above-mentioned conversational topic, it is necessary to study the grammatical linguistic material on the topic "The gender and number of the noun" and to master active vocabulary (grandfather, grandmother, father, mother, grandson, granddaughter, etc.; engineer, teacher, singer, pupil, student) from the named conversational topic, after which foreign students received the following tasks for independent work:

1) work on the model: in the group' s chat, a link was placed on the electronic textbook and a list of tasks aimed at automating the skills of using the learned grammatical forms using the active vocabulary of the conversational topic;

2) constructive-variable independent work was that students had to: connect through social networks with Ukrainian groupmates and ask them about their families, discuss in a group chat, with elements of minicompetition, which Ukrainian families are most interesting in the field of professional activities of their members (such tasks allowed to form and improve speech skills through the transfer of skills in new language situations);

3 ) at the stage of control, students did the following: a presentation of their own genealogical tree, using the example, given by the teacher through links to certain sources (in the form of a scheme or drawing), as well as a prepared monologue statement about their own family.

\section{Results and discussions}

The process and results of the distance learning course "Ukrainian language for foreign non-philology students" revealed a number of advantages and disadvantages, which confirmed the observations of previous researchers (Vymohy do struktury dystantsiinoho kursu, 2013; Chebotareva O.I., 2012). 
Among the advantages of the distance course, the following were recorded:

1) availability of the course at any time (foreign students of correspondence form of training have the opportunity to freely access the theoretical material of the course in Russian at the time convenient for them and themselves choose the pace of educational activities, but within the specified training modules):

2) the unlimited amount of information provided (the Internet allows foreign students to refer to a large number of additional sources during the course of studying);

3 ) the efficiency of providing information (electronic resources are updated more often than paper ones);

4) the flexibility of the organization of the learning process (distance learning allows to focus on more difficult topics of the course, leaving simple elements for self-study);

5) automation of the educational process (there is no need to compile a large number of identical types of tasks for the test and check the results of their implementation: the system will select any parameters at the request of the teacher and verify and save the results in the journal);

6) multimedia (in addition to traditional text and graphic information, remote e-learning naturally involves the use of all the multimedia capabilities in the process of creating methodological materials: animation, video, sound and color, which provides a clear presentation of the material and allows the use of most of the mechanisms of human perception of new information, thus contributing to increasing the efficiency of the educational process);

7) contributes to the formation of general educational competence (distance learning provides much more opportunities for independent work of the student, contributing to the formation of self-organization skills and rational planning of training time).

But, despite all the benefits, e-learning distance education has the following disadvantages: high demands for self-organization and student self-control; overly formalized learning and testing processes, which greatly complicates the provision of an individual approach; Extremely limited volume of practical classes; the exclusion from the process of direct motivating influence from the teacher, which takes place in the classroom work, as well as the impossibility of instant feedback from the teacher when it is necessary to receive immediate assistance; student' $\mathrm{s}$ inability to express their opinions orally; the formality of learning and testing knowledge.
Toimprovetheefficiency of theuse of distance learning tools the following recommendations "proven by practice" were proposed by K. Krechetnikov (Malitikov E.M. et al., 2001):

- providing the necessary tone from the very beginning of the course; thorough and detailed planning of the student' s activity, its organization; clear resolution of tasks and objectives of training;

- increasing the level of interactivity of electronic textbooks; providing feedback via e-mail, fax, audio and video conferencing, telephone;

- the time of students' communication with the teacher should be as long as possible and convenient for subjects of the educational process;

- development of necessary skills for students: technical; discussion management; self-study; critical thinking; information management, its selection and critical assessment;

- the structure of the course should be block-thematic: the student must clearly understand his progress from the topic to the topic.

In order to eliminate the shortcomings that were found during the experimental training, such an extramural distance learning form is subsequently introduced, through which students gain knowledge of the "Ukrainian Language" discipline by means of electronic distance courses, but the final control is carried out only in the presence of a teacher during face-to-face sessions. After all, we consider it expedient to apply a combined distance and distance learning, which combines tradition with innovation.

The structure of the course "Ukrainian language for foreign non-philology students", described above, allows combining the distance learning form and the traditional one, which greatly increases the efficiency of the organization of the educational process of foreign students of non-philological specialties and promotes the successful adaptation of the specified contingent to studying in universities.

\section{Conclusions}

Thus, the above-described requirements for the preparation of distance courses, the advantages and disadvantages, the structure of the distance course in the Ukrainian language for foreign students of non-philological specialties, developed on the basis of existing programs and taking into account the requirements for creating electronic distance courses, justify the appropriateness of the chosen way of compilation and applying courses in technical universities. Such distance courses 
help to meet the educational needs of students of correspondence form of training, provide a gradual learning of course materials and allow to create a virtual foreign language environment, which greatly increases the efficiency of the process of teaching Ukrainian as a foreign language.

The prospect of further research may be the development of principles for the creation of a distance learning web-quest complex on the Ukrainian language as a foreign language, which will help meet the communicative needs of foreign non-philology students in extracurricular time and provide independent work of students with all the necessary teaching materials.

\section{BIBLIOGRAPHY}

1. Аксенов Ю.В., Петров А.Е., Полат Е.С. Концепция дистанционного обучения на базе компьютерных телекоммуникаций. URL: https://journals.susu.ru/pit-edu/ article/view/174 (дата звернення: 05.07.2021).

2. Андреев А.А. Введение в дистанционное обучение : учебно-методическое пособие. Москва : BУ, 1997. 197 c.

3. Богомолов А.Н., Ускова О.А. Дистанционное обучение русскому языку как иностранному: обзор отечественных и зарубежных информационных технологий и методик. Москва : ЦМО МГУ, 2004. 74 с.

4. Вимоги до структури дистанційного курсу, затверджені рішенням Координаційної ради з питань електронного (дистанційного) навчання Харківського національного університету імені В.Н. Каразіна від 08.10.2013 p. Протокол № 2. URL: http://dist.karazin.ua/ moodle/course (дата звернення: 01.08.2021).

5 Гильмутдинов А.Х., Ибрагимов Р.А., Цивильский И.В. Электронное образование на платформе Moodle. Казань : КГУ, 2008. URL: https://uallib.org/book/74917 $1 / 0666 \mathrm{c} 5$ ? $\mathrm{id}=749171 \&$ secret=0666 5 (дата звернення: 01.08.2021).

6. Кречетников К.Г., Черненко Н.Н. Дистанционное обучение. Достоинства, недостатки, вопросы организации (аналитический обзор). URL: http://www. hr-portal.ru/article/distantsionnoe-obuchenie-dostoinstvanedostatki-voprosy-organizatsii-krechetnikov-k-g-cherne (дата звернення: 29.07.2021).

7. Малитиков Е.М., Карпенко М.П., Колмогоров В.П. Дистанционное образование в Российской Федерации и странах СНГ: вопросы теории и практики Телекоммуникации и информатизация образования. 2001. № 3. С. 16-36.

8. Про затвердження Положення про дистанційне навчання. Наказ МОН України, Положення від 25.04.2013 № 466. URL: http://zakon2.rada.gov.ua/laws/ show/z0703-13 (дата звернення: 21.07.2021).

9. Чеботарёва О.И. Методика адаптации учебных материалов для очно-дистанционного обучения английскому языку : автореф. дис. ... канд. пед. наук : 13.00.02. О.И. Чеботарёва; ФГОУ ВПО «Московский государственный университет имени М.В. Ломоносова». Москва, 2012. 26 с.

10. Alahuhta, P., Nordbäck, E., Sivunen, A., \& Surakka, T. (2014). Fostering team creativity in virtual worlds. Journal of Virtual Worlds Research, 7(3), 1-22. Retrieved March, 25, 2018. URL: https://journals.tdl.org/jvwr/index php/jvwr/article/view/7062 (дата звернення: 30.07.2021).

\section{REFERENCES}

1. Aksenov Iu.V., Petrov A.E., Polat E.S. (1998).Koncepcija distancionnogo obuchenija na baze komp' juternyh telekommunikacij [The concept of distance learning on the base of computer telecommunications]. http://www.phis. org.ru/education/ saityobr.shtml [in Russian].

2. Andreev A.A. (1997). Vvedenie v distancionnoe obuchenie: uchebno-metodicheskoe posobie [Introduction to distance learning: a manual]. Moscow: VU. 197 p. [in Russian].

3. Bogomolov A.N., Uskova O.A. (2004). Distancionnoe obuchenie russkomu jazyku kak inostrannomu: obzor otechestvennyh i zarubezhnyh informacionnyh tehnologij i metodik [Distance learning of the Russian language as a foreign language: a review of native and foreign information technologies and techniques]. Moscow: TSMO MGU. 74 p. [in Russian].

4. Vymohy do struktury dystantsiinoho kursu, zatverdzheni rishenniam Koordynatsiinoi rady $\mathrm{z}$ pytan elektronnoho (dystantsiinoho) navchannia Kharkivskoho natsionalnoho universytetu imeni V.N. Karazina vid 08.10.2013 r. [Requirements for the structure of the distance course, approved by the decision of the Coordination Council on questions of electronic (distance) education of the V.N. Karazin Kharkiv National University of 08.10.2013.] Protocol № 2. http://dist.karazin.ua/moodle/ course [in Ukrainian].

5. Gilmutdinov A.Kh., Ibragimov R.A. Tsivilskii I.V. (2008). Elektronnoe obrazovanie na platforme Moodle [E-learning on the Moodle platform]. Kazan: KGU. https:// ua1 lib.org/book/749171/0666c5? id=749171\&secret $=066$ $6 \mathrm{c} 5$ [in Russian].

6. Krechetnikov K.G., Chernenko N.N. (2001). Distancionnoe obuchenie. Dostoinstva, nedostatki, voprosy organizacii (analiticheskij obzor). [Distance learning. Advantages, disadvantages, questions of organization (analytical review)] http://www.hr-portal.ru/article/distantsionnoe-obuchenie-dostoinstva-nedostatki-voprosy-organizatsii-krechetnikov-k-g-cherne [in Russian].

7. Malitikov E.M, Karpenko M.P., Kolmogorov V.P. (2001). Distancionnoe obrazovanie v Rossijskoj Federacii i stranah SNG: voprosy teorii i praktiki [Distance education in the Russian Federation and CIS countries: questions of theory and practice]. Telekommunikacii $i$ informatizacija obrazovanija - Telecommunications and informatization of education, 3, 16-36. [in Russian].

8. Pro zatverdzhennia Polozhennia pro dystantsiine navchannia. Nakaz MON Ukrainy, Polozhennia vid 25.04.2013 № 466. [Order of the Ministry of Education and Science of Ukraine "On Approval of the Regulations on Distance Learning”. № 466, 25.04.2013] http://zakon2. rada.gov.ua/laws/show/z0703-13 [in Ukrainian].

9. Chebotareva O.I. (2012). Metodika adaptacii uchebnyh materialov dlja ochno-distancionnogo obuchenija anglijskomu jazyku [Methods of adaptation of educational materials for full-time and distance learning in English]. Abstract of dis. ... cand. ped. sciences: 13.00.02. Lomonosov Moscow State University, Moscow. 26 p. [in Russian].

10. Alahuhta, P., Nordbäck, E., Sivunen, A., \& Surak$\mathrm{ka}$, T. (2014). Fostering team creativity in virtual worlds. Journal of Virtual Worlds Research, 7(3), 1-22. Retrieved March, 25, 2018 from https://journals.tdl.org/jvwr/index. php/jvwr/article/view/7062 [in English].

Стаття надійила до редакиії 02.08.2021. The article was received 02 August 2021. 